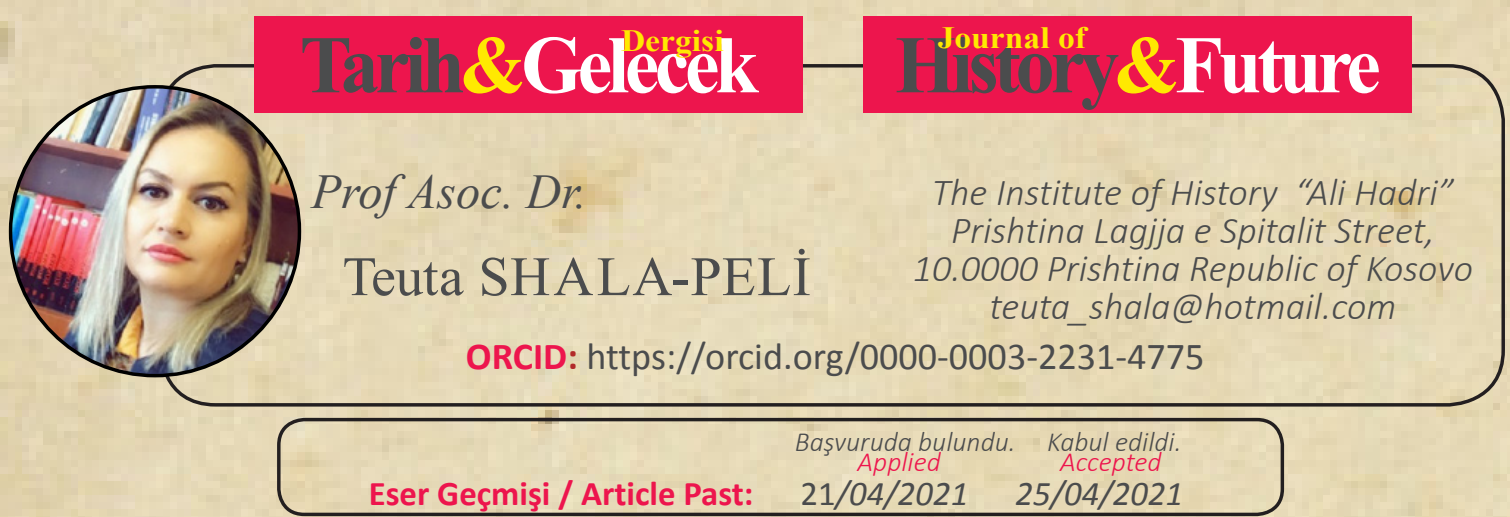

Araştırma Makalesi

DOI: http://dx.doi.org/10.21551/jhf.924011

Research Paper

Orjinal Makale / Orginal Paper

\title{
The Role of Dristian Priests as Notaries and Judges during the Middle Ages
}

\section{Ortaçağda Dristian Rahiplerinin Noterler ve Hakimler Olarak Rolü}

\begin{abstract}
Drisht (Latin: Drivastum) was a small medieval city located in northern part of Albania. The settlement of Drisht is known to have existed before the tenth century AD. During the ages Drisht became point of confrontation between Ragusian, Serbian, Albanian and Venetian rulers. Definitively Drisht was conquered by the Ottoman Empire in 1478. In this article, as far as the gathered data allowed us, we have presented some of the secular services provided by Drisht priests in and outside the city during the medieval period. The involvement of the Drisht priests in various secular services was an indication that they had exercised a strong influence on secular power. If analysing their secular-civil character activities, it appears that Drisht priests were involved in many directions: in the field of judiciary either as a judge or a participant in an ecclesiastical or secular trial; as a notary; in politics - signing political agreements, as it was the event of 1442 when Drishti came under the Venetian rule. Furthermore, they provided even notorious services outside of Drisht, as it was the case of priest Andrea, who in the early XIV century was mentioned as a notary in the island of Lagosta.
\end{abstract}

Keywords: Drishti, Middle age, priests, notary, judges.

\section{$\ddot{O} z$}

$\mathrm{Bu}$ çalışmada, dönemiın kaynakları izin verdiği kadar Drişt (Katolik) din adamlarının bazı laik görevlerin Drişt’te ve onun haricinde olanları sunduk. Orta Çağ Drişt din adamlarının farklı laik görevlerde faliyetleri neredeyse bütün laik hakimiyetinde tesirli olduğunu bir göstergesidir. Drişt din adamların laik-sivil karakterli konularda aktivitelerinin analizinden faliyetleri şu konularda destekte bulundular: adalet alanında yargıç olarak ve ya katılımcı olarak hem kilisie mahkemelerinde hem de laik 
olanlarında, yada noter gibi görevlerde bulundular; siyasette, siyasi anlaşmaların imzalanmalarına katılarak misal 1442 yılında olduğu gibi Drişt'in Venedik egemenliğine girdiği sırasında. Drişt din adamların Drişt’teki laik-sivil hizmetlere ek olarak, bu etkinliklerde özellikle noter olarak Drişt dışında da rastlayabiliris örneğin rahip Andreasın durumunda olduğu gibi, o XIV. yüzyılın başlarında Lagosta adasında noter olarak kaydageçmiştir. Bütün bunlar açıkça gösterir ki laik faliyetlerinde Drişt din adamların angajmanı çok boyutluydu.

Anahtar Kelimeler: Drişt, orta çağlar, noterler, hakemler.

\section{Introduction}

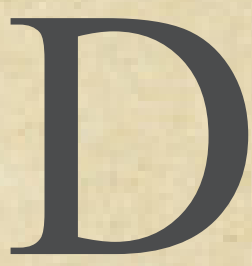

uring the Middle Ages Drishti, although a relatively small town, was distinguished for an active ecclesiastical life. Since its territory included a large number of church buildings as: cathedrals, churches and monasteries, certainly, there were also many priests who played a key role in organizing and developing many processes not only ecclesiastical but also secular. Such a fact is an indication that in Drisht the civil power along with the ecclesiastical one was almost entirely focused in the hands of the Drishtian priests, a power which over time became more and more reinforced, depending on the various political events and developments that occurred both in Albania and in neighbouring countries, which were also reflected in the town of Drishti. From the second half of the XIV century, in Drisht began to notice the increasing role and influence of the priests in civil services, because at this time in Drisht the priests gained civilian rule over the city. ${ }^{1}$

Indeed, the medieval historical sources often indicate the maintenance of civil-secular powers or services by priests of Drisht, as: attorney, a judge or a participant in both ecclesiastical and secular trials, in economics, in teaching, in testaments as a drafter, executor and witness, in political developments as a diplomat, as well as a warrior defending the city of Drishti against the Republic of Venice and the Ottoman Empire. So, the church or clergy in Drisht impacted a number of important areas, serving as a foothold for the economic, political, cultural, legal and wider processes of this city, which were the main pillars for its development during the Middle Age. In this paper, as far as the gathered data allow us, we will present some of the secular services of the Drishtian priests both in Drisht and abroad, from the beginning of the XIV century until after its fall under the Ottoman rule. One of the secular occupations where the Christian priests had a lot of influence was that of the notary. Unlike coastal cities such as Durrës (1243), Ulcinj (1261), Shkodra (1330), in which secular notaries operated, ${ }^{2}$ or from Tivari and Ulcinj, where notaries were Italian, ${ }^{3}$ in Drisht the occupation of notary was practiced by the priests who necessarily had to be from Drishti, so these were the two basic principles on the basis of which it was regulated to practice this occupation in the city of Drishti. The activity of the Drishtian priests as notaries, insofar as they provide us with the documents and literature available to us on this issue, can be

1 Milan Šufflay, Qytetet dhe kështjellat e Shqipërisë kryesisht në mesjetë, Onufri, Tiranë. 2009, 108-109."

2 Oliver Jenes Schmitt, Arbëria Venedike 1392-1479, K\&B, Tiranë. 2007, 140-141.

3 Statutet dhe urdhëresat e kapitullit të kishës katedrale të Drishtit, përgatitur nga Musa Ahmeti \& Etleva Lala, OMBRA GVG. Tiranë, 2009, 62. 
traced to the period 1317-1496. Apart from Drisht, there have been cases when Drishtian priests have served as notaries in other countries. Such a case was encountered since the beginning of the XIV century, it is about a priest from Drishti named Andrea, who in 1317 was mentioned as a notary on the island of Lagosta, ${ }^{4}$ which was under the rule of Dubrovnik. ${ }^{5}$

The earliest records of Drishtian priests who served as notaries in the town of Drishti are found in the year 1353. These data refers to the document of June 18, 1353, which has to do with the appointment of a governor from the Drishti chapter, in which case, as the signatory of that document was mentioned the public notary of Drishti, the priest (presbyteri) Gjon ( presbyteri Johannis publici iurati notarii). ${ }^{6}$ Fifteen years after that, in the year 1368, in Drisht, the bishop of Drisht, Gjoni, was mentioned as a notary. Whether it is the same person we mentioned above, or two different people, the documents on which we relied, both the year 1353 and the year 1368, do not allow us to state this. Despite this, it has been proven that in the town of Drishti in the period 1353-1442, served three notaries, who were local priests. ${ }^{7}$

However, Bishop Gjoni, who was apparently from the Lepore family, a well-known noble family from Drishti, ${ }^{8}$ had served as a bishop in Drishti for thirteen years, from 1360 to $1373 .{ }^{9}$ During his service as bishop, Gjon also served as the city's notary. Bishop Gjon, in the capacity of notary of the city of Drishti was found in a document from the year 1368. In this document which is dated on March 16, 1368, were mentioned some papers signed by Bishop Gjoni, public notary of the city of Drishti. ${ }^{10}$ The political climate created at the end of the XIV century in Northern Albania, as a result of political developments, was also reflected in Drishti's notary work. At the end of the XIV century the town of Drishti, which at that time was ruled by the feudal family of Balshaj, faced with two great dangers, on one side was the Republic of Venice and on the other side were the successive attacks of the Ottoman army. Situated in such a situation, Gergj II Strazimiri, in the year 1396, based on an agreement was forced to hand over the cities of Shkodra and Drisht to the Venetians, so that these would not fall into the hands of the Turks. ${ }^{11}$ The establishment of Venetian rule in the city of Drishti was, among other things, accompanied by numerous dissatisfactions from the ranks of notaries, because the new rule tried to bring about changes in the issue of notaries. This happened due to the fact that the Venetian rule tried in Durrës and in Northern Albania to abolish the notary system of the country. ${ }^{12}$

4 Konstantin Jireček, "Skutari und sein Gebiet im Mittelalter", Illyrisch-albanische Forschungen. Bd. 1, Wien, 1916, 112-113.

$5 \quad$ Šufflay, Qytetet dhe kështjellat e Shqipërisë, 160.

6 Ludovicus Thalloczy-Costantinus Jeriček-Emilianus Sufflay, Acta et diplomata res Albaniae mediae aetatis illustrantia, vol. II,Vindobonae. 1913-1918, 28.

7 Šufflay, Qytetet dhe kështjellat e Shqipërisë, 160.

8 Conrad Eubel, Hierarchia catholica medii aevi, sive Summorum pontificum, S.R.E. cardinalium, ecclesiarum antistitum series ab anno 1198 usque ad annum 1431 perducta e documentis tabularii praesertim Vaticani collecta, digesta, I. Monasterii. 1913, 227.

9 Daniele Farlato; Jacobo Coleto, et. al. Illyrici Sacri, vol. VII, Venetiis. 1817, 236.

10 Ludovicus Thalloczy, et. al. Acta et diplomata res Albaniae, 54.

11 Sime Ljubić, Listine, Listine o odnosajih izmedju juznoga Slavenstva i mletacke republike. Knjiga IV: od godine 1358 do 1403, Zagrebu. 1874, 365-369.

12 Sufflay, Qytetet dhe kështjellat e Shqipërisë, 163. 
The Republic of Venice intended to implement such a policy through its plan, where together with the Venetian governors in Albania were placed the accompanying notaries, who served for two years as well as the governors, and left together with them. ${ }^{13}$ With the establishment of their rule in Drisht, the Venetians in September 1396, established an office of power. ${ }^{14}$ Following these measures, a Venetian ruler was appointed to head Drishti's council, ${ }^{15}$ who, upon taking office, began to obstruct the work of Drishti's notary and favoured the Venetians, not allowing the notary to Drishti to make testaments and deeds, while the Venetian notaries for such acts took from the inhabitants as much money as they liked, thus violating the usual norms of the time. ${ }^{16}$

Since such a plan was opposed by the locals, Venice was forced as early as the year 1397 , a year after the establishment of the rule in Drisht, to give permission to the Drishtians to keep their notary and give them work. ${ }^{17}$ In this regard, on July 5, 1397, Venice returned answers to the publishers of the city of Drishti on some internal issues of that city. Among the issues mentioned was that of the notary. ${ }^{18}$

In the following years the documents of the time testify to the role of Drishti's notary in the political developments that took place in this city after the death of Balsha III. As the city of Drishti was known in the period 1396-1421, it appears to us sometimes under the ownership of the feudal family of Balshaj and sometimes under the ownership of the Republic of Venice. In the year 1421 the Republic of Venice, taking advantage of the death of Balsha III (1421), managed to seize some of the Balshaj possessions and to annex them to its own domains in Albania, among which was the city of Drishti. Referring to the documentary data, it is noticed that the city of Drishti since July 1421 was mentioned a city under the possessions of Venice. ${ }^{19}$

However, the Republic of Venice did not have a peaceful rule in these cities until 1442, when the signed documents defined the conditions under which the city of Drishti passed under the rule of Venice. These documents were signed on August 5, 1442 between the representatives of the Republic of Venice and the representatives of the municipality of Drishti, consisting of Bellacius Ungari (Bellacius Vngaro), Bellus Precali (judge), Teodor Kilanci (Theodorus Chilanzo) ( judge), Gjon Bello (Johannes Bello), Nikolle Skaputari and priest Pal as notary of the city. ${ }^{20}$ Three years after the signing of this agreement, the notary of the city of Drishti, the priest Pal (Pal Martushi), in September 1445 was forced to go to Venice to demand that the governors of Drishti recognize him as the notary of the municipality as he had been elected by as well as the official guarantee (relevant act) from senior Venetian officials. ${ }^{21}$ As we pointed out at the beginning of this study, we

13 Luan Malltezi, Qytetet e bregdetit shqiptar gjatë sundimit venedikas 1392-1478(Aspekte të jetës së tyre), Akademia e Shkencave e RPS të Shqipërisë-Instituti i Historisë, Tiranë. 1988, 213.

14 Ludovicus Thalloczy, et. al. Acta et diplomata res Albaniae, 153-154.

15 Konstantin Jireček, "Skutari und sein Gebiet im Mittelalter", Illyrisch-albanische Forschungen. Bd. 1, Wien. 1916, 112.

16 Ludovicus Thalloczy, et. al. Acta et diplomata res Albaniae, 165-166.

17 Šufflay, Qytetet dhe kështjellat e Shqipërisë, 163.

18 Ljubić, Listine o odnosajih izmedju juznoga Slavenstva i mletacke republike, (1358 do 1403), 408.

19 Giuseppe [Josephi] Valentini, Acta Albaniae Veneta saeculorum XIV et XV, 25 vol., Archivio di Stato di Venezia, Palermo-Napoli-Roma-Venezia-München. 1967-1972, p. II, t. 11, no. 2503, 6.

20 Giuseppe [Josephi] Valentini, Acta Albaniae Veneta saeculorum XIV et XV, p. II, t. 17, no. 4057, 226.

21 Malltezi, Qytetet dhe kështjellat e Shqipërisë, 214-215. 
have encountered in some cases when priests from Drishti have served as notaries outside Drishti. Such cases are also mentioned in Venice after the fall of Drishti under Ottoman rule in 1479, where a part of the Drishtian clergy who migrated to Venice was fortunate enough to get integrated into the ecclesiastical life of that country. Among them Jakob Sapa from Drishti was mentioned, who was a parish priest and notary in the church of St. Mary the Mother of God from the years 1487 to 1496.22

In the legal sphere the Drishtian priests also had influence in the judiciary; certain persons from the ranks of the clergy were obliged to participate in both ecclesiastical and secular trials. Related to this in Statutes and directions of the chapter of the cathedral church of Drishti, in chapters $I V$ and $V$ of these Statutes, which defined the duties of rector and of procurator it was said that both the rector and the prosecutor had to attend any trial, both ecclesiastical and secular, even the rector had the right to reverse the sentences, or give other sentences to those who disobeyed. He controlled the revenue within the canon wherever they came from. ${ }^{23}$ When it comes to the field of judiciary, referring to the Statutes of the city of Drishti, moreover, the Drishtian clergy had particular influence in matters of an ecclesiastical nature. In the Statutes of the city of Drishti, we come across some provisions which set out the matters to be tried within the chapter of Drishti Cathedral Church, some of which were tried by the rector, who was apparently authorized and had the right to try all those who did not adhere to the rules which were set out within the Statutes of the city of Drishti.

From the first chapter of these statutes, which speaks of mutual respect both from the young to the elderly and vice versa, the rector was authorized to punish all those who did not adhere to this rule, "the offender is punished in the chapter by the rector and by the elders according to guilt. ${ }^{24} \mathrm{Also}$, the articles of these statutes speak of a series of punishments that were foreseen for those who are thieves and fraudsters in the affairs of the canon (chapter XXIII), ${ }^{25}$ as well as for violent persons, for example, punishments were provided for all those who hit the table with their fist (chapter XXVIII), ${ }^{26}$ as well as for the person who beats another person (chapter XXIX), ${ }^{27}$ were also punished all those who played dice or any other dishonest game ( chapter XXXVII ${ }^{28}$ In order for judgments to be fair and impartial, those who judged others swore that they would make unblemished judgments (Chapter XXXIV), ${ }^{29}$ thus expressing the credibility of those who judged others. Drishtian priests in certain cases defended the rights of Drishtian citizens when they were denied by local government officials serving in the city of Drisht. In a document dated April 7, 1407, when a woman named Marabona from Drishti was wronged by a deputy of Drishti, regarding the will of her husband, the priest Moisi (Moyses) from Drishti was mentioned, who on behalf of Mrs. Marabona (Marabone), widow of Mr. Mikel Berla (Michaelis Berla), resident in Drisht, had complained against the noble man,

22 Lucia Nadin, Shqiptarët në Venedik. Mërgim dhe Integrim 1479-1552", Shtëpia Botuese "55", Tiranë. 2009, 55.

23 Statutet dhe urdhëresat e kapitullit të kishës katedrale të Drishtit, Head: IV, 145-146.

24 Ibid, Head: I, 144.

25 Ibid, Head: XXIII, 155.

26 Ibid, Head: XXVIII, 157.

27 Ibid, Head: XXIX, 158.

28 Ibid, Head: XXXVII, 162.

29 Ibid, Head: XXXIV, 161. 
Mr. Pal Bonci (Paulus Bonci), who had been the deputy of Drishti, claiming that: “...that Mr. Pal, contrary to the form of the will of Mikel Berla and the two decisions taken by his predecessors, in favour of the will in question, contrary to what he could and should have done, has broken and cancelled them decisions by means of a decision he made...". ${ }^{30}$

These examples are a good proof and indication that the clergy in the town of Drishti during the Middle Age had extended their influence in the field of law, practicing the profession of notary and judge.

\section{Conclusion}

The involvement of the Drisht priests in various secular services was an indication that the priests in Drisht during the Middle Age, exactly during the period we elaborate in this paper, had almost entirely influence on secular powers. From the analysis of their activity in matters of secular-civil character, the priests of Drisht, through their engagement assisted in the field of judiciary either as a judge or as a participant in any trial both ecclesiastical and secular (secular), as well as a notary. Additionally, the Drisht priests provided civil-secular services even abroad, as: the priest Andrea, who in the early XIV century was mentioned as a notary working in the island of Lagosta, and the case of the parish priest Teodor, who since the end of the XIV century had served as a teacher in Stanjo Dubrovnik. All this clearly shows that the involvement of the priests in the secular services was very dimensional.

\section{Bibliography}

Dokumente për historinë e Shqipërisë të shek.XV, vol. II (1406-1410), Akademia e Studimeve Albanologjike-Instituti i Historisë, Tiranë, 2019.

Eubel, Conrad, Hierarchia catholica medii aevi, sive Summorum pontificum, S.R.E. cardinalium, ecclesiarum antistitum series ab anno 1198 usque ad annum 1431 perducta e documentis tabularii praesertim Vaticani collecta, digesta, I. Monasterii, 1913.

Farlato, Daniele; Coleto, Jacobo, et. al. Illyrici Sacri, vol. VII, Venetiis, 1817.

Jireček, Konstantin , "Skutari und sein Gebiet im Mittelalter", Illyrisch-albanische Forschungen. Bd. 1, Wien, 1916.

Ljubić, Sime ,Listine, Listine o odnosajih izmedju juznoga Slavenstva i mletacke republike. Knjiga IV: od godine 1358 do 1403, Zagrebu, 1874.

Malltezi, Luan, Qytetet e bregdetit shqiptar gjatë sundimit venedikas 1392-1478(Aspekte të jetës së tyre), Akademia e Shkencave e RPS të Shqipërisë-Instituti i Historisë, Tiranë, 1988.

Nadin, Lucia , Shqiptarët në Venedik. Mërgim dhe Integrim 1479-1552", Shtëpia Botuese "55", Tiranë, 2009.

Schmitt, Oliver Jenes, Arbëria Venedike 1392-1479, K\&B, Tiranë, 2007.

30 Dokumente për historinë e Shqipërisë të shek.XV,vol. II (1406-1410), Akademia e Studimeve Albanologjike-Instituti i Historisë, Tiranë. 2019, 124. 
Statutet dhe urdhëresat e kapitullit të kishës katedrale të Drishtit, përgatitur nga Musa Ahmeti \& Etleva Lala, OMBRA GVG, Tiranë, 2009.

Šufflay, Milan, Qytetet dhe kështjellat e Shqipërisë kryesisht në mesjetë, Onufri, Tiranë. 2009.

Thalloczy, Ludovicus - Jeriček, Costantinus - Sufflay, Emilianus, Acta et diplomata res Albaniae mediae aetatis illustrantia, vol. II,Vindobonae, 1913-1918.

Valentini, Giuseppe [Josephi], Acta Albaniae Veneta saeculorum XIV et XV, 25 vol., Archivio di Stato di Venezia, Palermo-Napoli-Roma-Venezia-München, 1967-1972. 